\title{
Substance P Receptors on Canine Chief Cells: Localization, Characterization, and Function
}

\author{
Steven R. Vigna, ${ }^{1,2, a}$ Christopher R. Mantyh,, ${ }^{1,2}$ Andrew H. Soll,, ${ }^{1,2}$ John E. Maggio, ${ }^{3}$ and Patrick W. Mantyh 1,2,4 \\ 'Department of Medicine, UCLA School of Medicine, Los Angeles, California 90024, ${ }^{2}$ Center for Ulcer Research and \\ Education, V. A. Wadsworth Medical Center, Los Angeles, California, 90073, ${ }^{3}$ Department of Biological Chemistry and \\ Molecular Pharmacology, Harvard Medical School, Boston, Massachusetts 02115, and ${ }^{4}$ Brain Research Institute, UCLA \\ School of Medicine, Los Angeles, California 90024
}

Saturable binding sites for ${ }^{125}$-Bolton-Hunter substance $P$ were observed in frozen sections of the oxyntic mucosa of the canine stomach using quantitative autoradiography. The cell type possessing substance $P$ binding sites in this region was identified as the chief cell in 2 ways. First, the saturable binding of radioiodinated substance $P$ correlated with chief cell content (and not with parietal cell content, for example) in dispersed oxyntic mucosal cells fractionated by centrifugal elutriation. Second, saturable binding of radioiodinated substance P was localized to dispersed chief cells by autoradiography using emulsion-coated preparations of isolated cells affixed to glass slides. Parietal and mucous cells did not bind substance P. In studies of enriched chief cell preparations, the binding of radiolabeled substance $P$ was found to be time- and cell number-dependent, specific, saturable, reversible, and of high affinity. Equilibrium binding analysis revealed a single class of binding sites with an apparent $K_{d}$ of 105 pM and a $B_{\max }$ of 3000 receptors per cell. In competitive displacement studies, the order of potency of analogs for inhibition of the saturable binding of radiolabeled substance $P$ to chief cells was substance $P=$ physalaemin > substance $K>$ neuromedin $K$; thus, the chief cell has a substance P-preferring tachykinin binding site. Bombesin, cholecystokinin, and somatostatin had no effect on substance $P$ binding. Substance $P$ stimulated pepsinogen secretion from isolated canine oxyntic glands in dose-dependent fashion with a half-maximal response occurring at a substance $P$ dose of about $1 \mathrm{~nm}$. Substance $P$ also dosedependently stimulated increases in intracellular calcium concentrations in canine oxyntic glands, elutriation-enriched chief cells, and highly enriched, density gradient-purified chief cells at substance $P$ concentrations similar to those

Received Oct. 17, 1988; revised Jan. 3, 1989; accepted Jan. 20. 1989.

We thank Roy Lau for excellent technical assistance. This work was suppored by the American Heart Association (Southern California Chapter), Amyotrophic Lateral Sclerosis Association. Southem California Arthritis Foundation, an Alfred Sloan Fellowship (P.W.M.), SmithKline Beckman Fellowships (S.R.V.. P.W.M.). N1H grants AM 17328 (CURE Center Grant). DK40260 (S.R.V.). DK 19984 and DK 30444 (A.H.S.), NS23970 (P.W.M.), NS22961, RR05381 (J.E.M.), and NSF grant DCB-8542227 (S.R.V.).

Correspondence should be addressed to Patrick W. Mantyh. Research Service (I51). VA Medical Center, I Veterans Drive, Minncapolis, MN 55417.

- Present address: Department of Cell Biology. Box 3709. Duke University Medical Center, Durham, NC 27710.

Copyright ce 1989 Socicty for Neuroscience 0270-6474/89/082878-09\$02.00/0 effective in the radioligand displacement and pepsinogen release studies. We conclude that canine chief cells possess substance $P$ receptors coupled to a calcium secondmessenger system and that substance $P$ stimulates pepsinogen secretion. The present study outlines a general strategy whereby the expression of a specific receptor binding site in an identified cell type can be correlated with a physiologically relevant function, provided that methods for obtaining enriched populations of the subject cells are available.

A common problem in quantitative receptor autoradiography and homogenate receptor binding experiments is demonstrating that specific binding sites correspond to functional receptors and that activation of these receptors by a ligand produces a functionally relevant response. Thus, while radioligand studies can define the tissue distribution, the cell type, and the pharmacological profile corresponding to a particular binding site, these studies alone generally do not address functional relevance of receptor expression.

An example of this problem is the expression of substance $P$ receptor binding sites in the gastrointestinal tract. Substance $P$ (a member of the tachykinin family of neuropeptides) is distributed widely in the mammalian gastrointestinal tract. With the exception of a few mucosal enterochromaffin cells, substance $P$ in the gut arises from a set of neurons in the myenteric and submucosal plexuses and from sensory neurons with cell bodies in the nodose and dorsal root ganglia (Schultzberg et al., 1980; Malfors et al., 1981; Minagawa et al., 1984; Sharkey et al., 1984). Substance $P$ has been implicated in regulating such diverse gut functions as mucosal ion transport (Kachur et al., 1982), motility (Bury and Mashford, 1976, 1977; Nieber et al., 1981), blood flow (Lembeck and Holzer, 1979), the excitability of enteric neurons (Katayama and North, 1979), and the inflammatory and immune responses (Mantyh et al., 1988a, b).

In a recent study (Mantyh et al., 1988b), we defined the distribution in the canine gastrointestinal tract of cell types expressing receptor binding sites for the members of the tachykinin family of bioactive peptides, substance $P$, substance $K$ (also known as neurokinin $\alpha$, neuromedin $\mathrm{L}$, and neurokinin $\mathrm{A}$ ), and neuromedin $\mathrm{K}$ (also known as neurokinin $\beta$ and neurokinin $B$ ). The tissues of the canine gastrointestinal tract are similar, both histologically and functionally, to the corresponding human tissues, and offer a degree of anatomical resolution not attainable 
with rodent tissues. From these studies we concluded that substance P binding sites were localized to smooth muscle cells in the muscularis mucosa and muscularis externa, the smooth muscle and endothelium of arterioles and venules, neurons in the myenteric plexus, mucosal epithelial cells, exocrine cells, and lymph nodules. Substance $\mathrm{K}$ binding sites were distributed in a pattern distinct from substance $P$ binding sites and were localized to smooth muscle cells in the muscularis mucosa and muscularis externa, the smooth muscle and endothelium of arterioles and venules, and neurons of the myenteric plexus. Neuromedin $\mathrm{K}$ binding sites were not observed in any area of the canine gastrointestinal tract using radioligands and experimental protocols that do detect neuromedin $\mathrm{K}$ binding sites in the brain and spinal cord.

While autoradiographic studies may suggest the cell types that are targets for a particular neurotransmitter, the exact cell type (at the single cell level) expressing the receptor binding site in each tissue requires further resolution. Furthermore, localization studies do not reveal whether stimulation of the receptor binding site leads to a functionally relevant response. In the present studies, we focused on an area of the canine stomach that demonstrated a high concentration of saturable substance $P$ binding sites but where the exact cell type expressing the putative receptors was unknown (because of the very high packing density of many different cell types in this area) and where the functional response to substance $P$ was unknown.

The studies described here were designed to identify the cell type present in the oxyntic mucosa possessing saturable substance $P$ binding sites, to characterize the properties of these binding sites with a view toward determining if they are physiologically significant receptors, and to correlate the properties of the receptors with a biological function.

\section{Materials and Methods}

Autoradiography. The specific binding of ${ }^{125} \mathrm{I}$-Bolton-Hunter substance $\mathrm{P}$ to canine gastric tissue sections was determined as previously described (Mantyh et al., 1988b). Briefly, synthetic substance P (Bachem) was iodinated using the Bolton-Hunter reagent $[N$-succinimidyl 3-(4hydroxy, 3-(125I)iodophenyl)propionate; New England Nuclear] and purified by reverse-phase HPLC to a specific activity of $>2000 \mathrm{Ci} /$ mmol. Mongrel dogs were killed by intravenous barbiturate overdose and tissue rapidly removed, frozen on dry ice in Tissue-Tek O.C.T. Compound (Miles), and then serially sectioned at $30 \mu \mathrm{m}$, thaw-mounted onto gelatin-coated glass slides, and stored desiccated at $-70^{\circ} \mathrm{C}$ until analysis. The slide-mounted tissue sections were then preincubated in a buffer containing $0.005 \%$ (vol $/ \mathrm{vol}$ ) polyethylenimine, followed by incubation in a solution containing $100 \mathrm{pm}^{125}$ I-Bolton-Hunter-substance $\mathrm{P}$. To estimate the nonsaturable binding, paired serial sections were incubated identically except that $1 \mu \mathrm{M}$ nonradioactive substance $\mathrm{P}$ was added to the incubation solution. The slides were then rinsed and quickly dried under a stream of cold air. After drying, the slides were apposed to LKB tritium-sensitive Ultrofilm for $1-4$ wecks, and then the film was developed in Kodak D-19 developer, fixed, and washed. Sections adjacent to those used for autoradiography were stained with hematoxylin and eosin (H\&E) and mounted with Histoclad. Bright-field photomicrographs were then taken of the H\&E-stained sections and the Ultrofilm to generate 3 complementary images: the Ultrofilm autoradiograms of (1) total and (2) nonsaturable ${ }^{125} I$-Bolton-Hunter substance $P$ binding and (3) the H\&E-stained section that provided histological orientation and identification of tissues expressing substance $P$ binding sites. Controls for chemographic artifacts were generated by performing the binding exactly as described above except that the radioligand was omitted from the incubation medium.

For precise cellular localization of saturable substance $P$ binding, cell suspensions were incubated with $300 \mathrm{pm}^{125}$ [-Bolton-Hunter-substance $P$ in the presence or absence of $1 \mu \mathrm{M}$ nonradioactive substance $P$, and then the cells were washed twice in ice-cold incubation medium without substance $P$ and affixed to glass slides by centrifugation. The slides were then air-dried and exposed to paraformaldehyde vapors at $80^{\circ} \mathrm{C}$ for 1 hr (Herkenham and Pert, 1982) to fix the cells. These slides were then coated with Kodak NTB-2 emulsion and exposed for 4 weeks. After these emulsion-coated autoradiograms were developed, the sections were placed in Carnoy's fixative for $3 \mathrm{hr}$, stained with $\mathrm{H} \& \mathrm{E}$, and mounted with Histoclad. Dark- and bright-field photomicrographs were then taken of the silver grains and counterstained sections, respectively. Using this method, it was possible to obtain both detailed cytological resolution of the saturable ${ }^{125} \mathrm{I}$-Bolton-Hunter substance $\mathbf{P}$ binding sites (dark-field) and identification of the exact cell type (bright-field) expressing the binding sites.

Cell dispersion and separation. Cells were dispersed from canine oxyntic mucosa by using techniques adapted from those previously described (Soll, 1978). Briefly, the oxyntic mucosa was bluntly separated from submucosa and then sequentially incubated in crude collagenase $(0.25 \mathrm{mg} / \mathrm{ml})$ and EDTA $(1 \mathrm{mM})$. Cell separation was performed using a Bcckman clutriator rotor (Soll, 1978; Ayalon et al., 1982). Fractions were collected according to the protocol described previously (Soll, 1978). In addition, in some experiments, highly enriched chief cell fractions were prepared using stepwise density-gradient centrifugation as previously described (Soll et al., 1984).

Substance $P$ binding studies. Cells prepared as described above were suspended in Hanks' Balanced Salt Solution (HBSS) fortified with 10 mM Hepes and $0.1 \% \mathrm{BSA}$ and adjusted to $\mathrm{pH} 7.4$. Cells were used at a final concentration of $2 \times 10^{6} / \mathrm{ml}$ unless otherwise specified. Total binding was determined using concentrations of ${ }^{125}$ I-Bolton-Hunter-substance $P$ of $10-100 \mathrm{pM}$, and nonsaturable binding was determined in the presence of $1 \mu \mathrm{M}$ nonradioactive substance $P$. The results shown represent saturable binding (total binding minus nonsaturable binding) unless otherwise specified. Binding was performed in $16 \times 100 \mathrm{~mm}$ polystyrenc tubcs. The tubes were incubated for $30 \mathrm{~min}$ (unless otherwise noted) at $37^{\circ} \mathrm{C}$ in a shaking water bath at 120 oscillations $/ \mathrm{min}$. At the end of the incubation period, cell-associated radioactivity was separated from free radioactivity by centrifugation of triplicate $0.3 \mathrm{mil}$ samples of cell suspension for $30 \mathrm{sec}$ in a microfuge (Beckman model B) in $0.4 \mathrm{ml}$ polyethylene microcentrifuge tubes. The supernatant was aspirated to waste and the pelleted cells were washed with $0.3 \mathrm{ml}$ of ice-cold incubation solution and recentrifuged. the tips of the tubes containing the washed, pelleted cells were cut off and counted in a gamma spectrometer.

Pepsinogen release studies. It has been reported that acutely prepared isolated canine chief cells do not secrete pepsinogen in response to secretagogues (Sanders et al., 1983). Therefore, we used a preparation of canine gastric glands to study substance P-stimulated pepsinogen secretion. Gastric glands werc prepared as described above for oxyntic cells except that minced oxyntic mucosa was subjected to 2 incubations for $45 \mathrm{~min}$ each in the presence of $1 \mathrm{mg} / \mathrm{ml}$ of crude collagenase (Sigma Type I) and the EDTA incubation was omitted. After filtering the incubate through $250 \mu \mathrm{m}$ nylon mesh, the glands were resuspended in an incubation solution consisting of $128 \mathrm{~mm} \mathrm{NaCl}, 4.7 \mathrm{mM} \mathrm{KCl}, 0.56 \mathrm{~mm}$ $\mathrm{MgCl}_{2}, 1 \mathrm{~mm} \mathrm{NaH} \mathrm{PO}_{4} \cdot \mathrm{H}_{2} \mathrm{O}, 2.55 \mathrm{~mm} \mathrm{CaCl}, 2 \mathrm{~mm}$ glutamine, $20 \mathrm{mM}$ Hepes, $5 \mathrm{~mm}$ glucose, $2 \mathrm{~mm}$ essential and nonessential amino acids, and $0.1 \% \mathrm{BSA}, \mathrm{pH} 7.4$. Gastric glands prepared from $1 \mathrm{gm}$ oxyntic mucosa were suspended in $50 \mathrm{ml}$ incubation solution. Various concentrations of substance $P$ were incubated in triplicate with $0.5 \mathrm{ml}$ of gland suspension for $1 \mathrm{hr}$ at $37^{\circ} \mathrm{C}$ at 210 oscillations $/ \mathrm{min}$ in $16 \times 100 \mathrm{~mm}$ polystyrene tubes gassed with $100 \% \mathrm{O}_{2}$ and capped with silicone rubber stoppers. After incubation, the tubes were placed on ice, and then the gland suspensions werc transferred to $1.5 \mathrm{ml}$ microcentrifuge tubes and centrifuged for $1 \mathrm{~min}$ in a microfuge (Beckman Model B). The supernatants were saved on ice for later pepsinogen assay. Triplicate samples of $0.5 \mathrm{ml}$ gland suspension were snap-frozen on dry ice and then thawed for $30 \mathrm{~min}$ at room temperature to liberate total glandular plus medium pepsinogen content for estimation of the total amount of pepsinogen present in the incubates. Pepsinogen was assayed by a modification of the method of Anson and Mirsky (1932). Samples (100-200 $\mu$ l) were added to $3 \mathrm{ml}$ of ice-cold $1 \%$ bovine hemoglobin (Sigma) dissolved in $0.1 \mathrm{~N} \mathrm{HCl}$. The tubes were mixed and then incubated for $10 \mathrm{~min}$ at $37^{\circ} \mathrm{C}$ in a water bath at 120 oscillations $/ \mathrm{min}$. After this incubation, the tubes were immersed in ice water for $5 \mathrm{~min}$ and $5 \mathrm{ml}$ of $10 \%$ trichloroacetic acid was added to each tube; the tubes were then incubated on ice for $10 \mathrm{~min}$. Each sample was then filtered through Whatman \#3 paper at unit gravity and the filtrate diluted 1:5 with distilled water. TCA-soluble protein in the filtrates was determined by the technique 


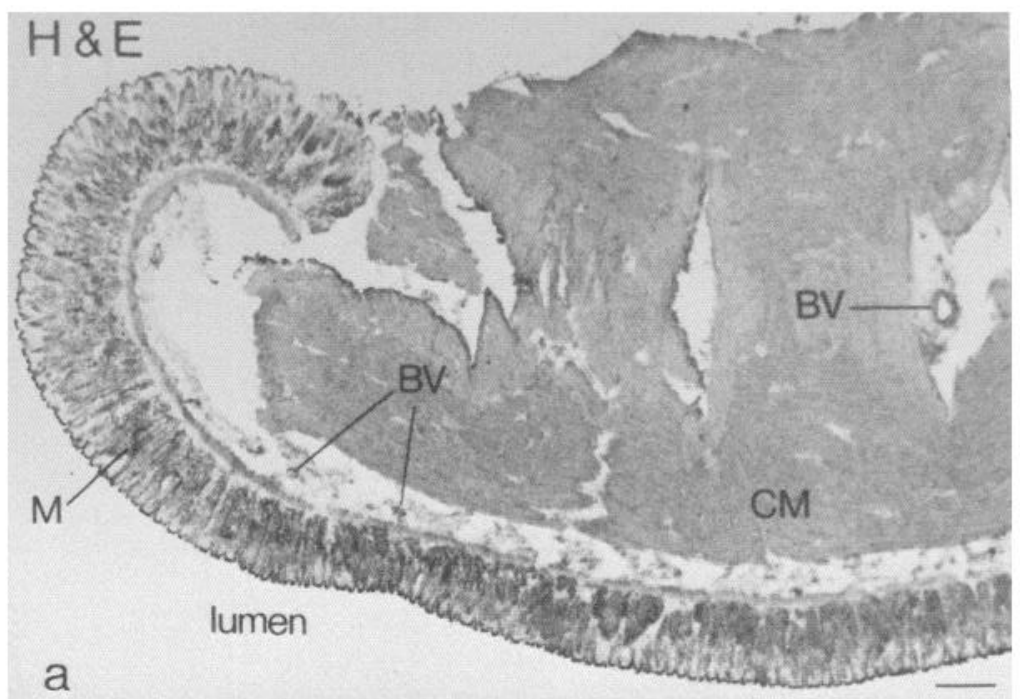

Figure 1. Distribution of ${ }^{125}$ I-BoltonHunter substance $P$ binding sites in the canine oxyntic stomach, $a$, Bright-field photomicrograph of a section of the canine oxyntic stomach stained with hematoxylin and eosin (H\&E). $b$, Darkfield photomicrograph of the LKB tritium-sensitive film that overlaid $a$. The white silver grains represent high concentrations of ${ }^{125} \mathrm{I}$-Bolton-Hunter substance $\mathrm{P}$ binding sites. $c$, Dark-field photomicrograph of a section adjacent to and treated identically to $b$ except that nonradioactive substance $\mathrm{P}(1 \mu \mathrm{M})$ was added to the incubation solution. Note the high concentrations of ${ }^{125} \mathrm{I}$ Bolton-Hunter substance $P$ specific binding sites in the basal two-thirds of the oxyntic mucosa in $b$. Smooth muscle in the external muscle layers and in blood vessels also exhibited specific binding sites for ${ }^{125} \mathrm{I}$-Bolton-Hunter substance P. Abbreviations: $B V$, blood vessel; $C M$, circular muscle; $M$, mucosa; ${ }^{125} I S P$, ${ }^{125}$ I-Bolton-Hunter substance P. Scale bar, $0.8 \mathrm{~mm}$.
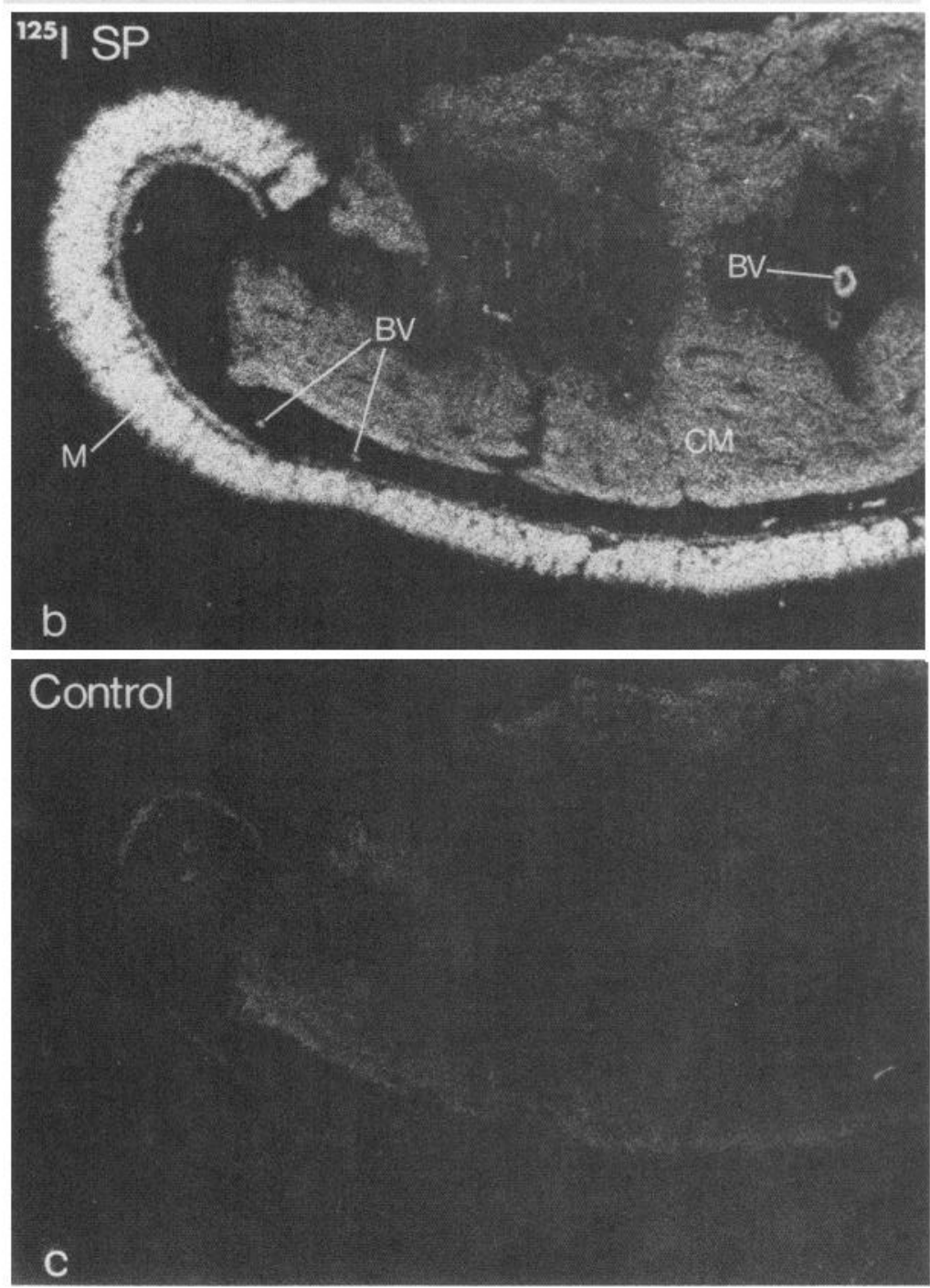

of Bradford (1976) using the BIO-RAD microassay procedure. The results are expressed as the amount of pepsinogen released into the incubation solution as a percentage of the total amount of pepsinogen present in the glands plus incubation solution at the beginning of the incubation. Basal secretion has been subtracted from all reported values.
Studies of intracellular calcium concentrations. Elutriated fractions enriched in chief cells, highly purified chief cell fractions obtained using step density-gradient centrifugation, and gastric glands were used to examine the effect of substance $\mathbf{P}$ on intracellular calcium concentrations. FURA-2/AM (Molecular Probes, Eugene, OR) fluorescence mea- 

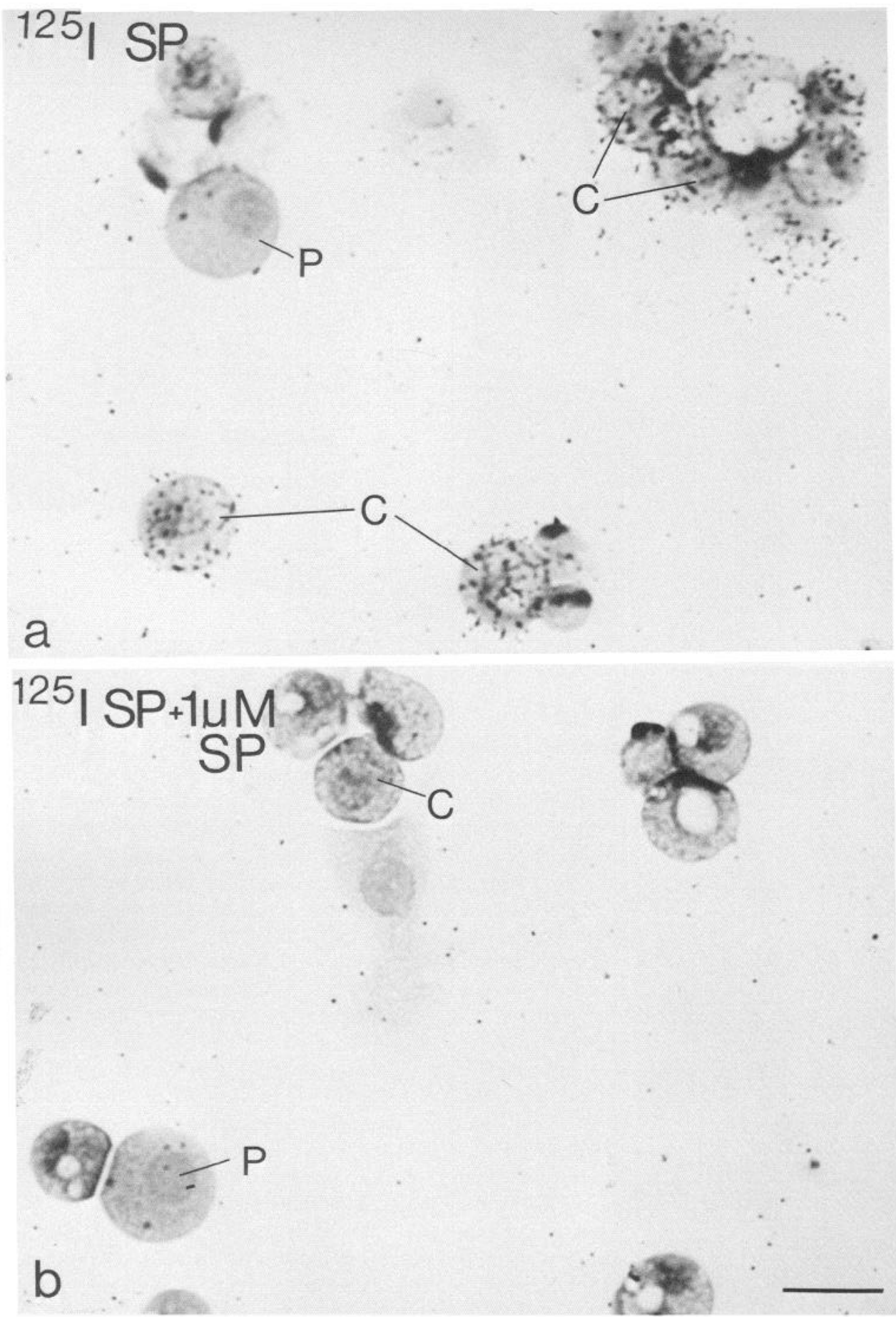

Figure 2. Distribution of ${ }^{125} \mathrm{I}$-BoltonHunter substance $\mathrm{P}$ binding sites on dispersed cells from the canine oxyntic mucosa. Dispersed oxyntic mucosal cells were incubated with ${ }^{125}$ I-BoltonHunter substance $\mathbf{P}$ in the absence $(a)$ or presence $(b)$ of nonradioactive substance P $(1 \mu \mathrm{M})$. After incubation to equilibrium, the cells were washed twice with cold buffer and then affixed to a glass slide by centrifugation. After fixation as described in Materials and Methods, the slides were coated with photographic emulsion and exposed for 4 weeks. After developing the emulsion, the cells were stained with $H \& E$ and coverslipped. $a$. Black silver grains representing accumulation of ${ }^{125}$ I-Bolton-Hunter substance $\mathrm{P}$ are present over chief cells but not over the parietal cell in the field (the largest cell present). $b$, Control incubation demonstrates that the accumulation of ${ }^{125}$ I-Bolton-Hunter substance $\mathrm{P}$ over chief cells is specific because it is abolished by coincubation with $1 \mu \mathrm{M}$ nonradioactive substance $\mathrm{P}$. Scale bar, $15 \mu \mathrm{m}$. surements were performed in a SLM-Aminco model 8000 Spectrofluorometer. Cells $\left(1.5 \times 10^{6} / \mathrm{ml}\right)$ or glands were loaded in the presence of $1 \mu \mathrm{M}$ FURA-2/AM for $5 \mathrm{~min}$ at $37^{\circ} \mathrm{C}$ in Hanks' buffer $\left(1.8 \mathrm{mM} \mathrm{Ca}^{2+}\right.$, $\mathrm{pH}$ 7.4) with shaking in a water bath. Care was taken to keep the cells or glands at $37^{\circ} \mathrm{C}$ at all times after loading. The spectrofluorometer cuvette was thermostatically controlled at $37^{\circ} \mathrm{C}$, and the cell or gland preparations were continuously stirred in the cuvette. $\mathrm{A} 1 \mathrm{~cm}$ path length polystyrene cuvette was used and the volume of cell or gland suspension was $2 \mathrm{ml}$. The excitation monochromator was shifted between 340 and $380 \mathrm{~nm}$ at $1 \mathrm{sec}$ intervals and emission was measured at $510 \mathrm{~nm}$. Maximal fluorescence was measured after lysing the cells with $0.75 \%$
Triton X-100 for $15 \mathrm{sec}$ and minimal fluorescence was determined subsequently after quenching with 20 mM EGTA.

Data analysis. In studies of substance $P$ binding and stimulation of pepsinogen release, the means of triplicate determinations for each treatment have been used for subsequent analysis. Where mean values are given they are followed by \pm SEM.

The data from each radioligand binding study were fit separately to receptor binding models using the programs EBDA (McPherson, 1985) and LIGAND (Munson and Rodbard, 1980). Means \pm SEM of the resulting estimated binding constants were computed $(n=$ number of animals). 


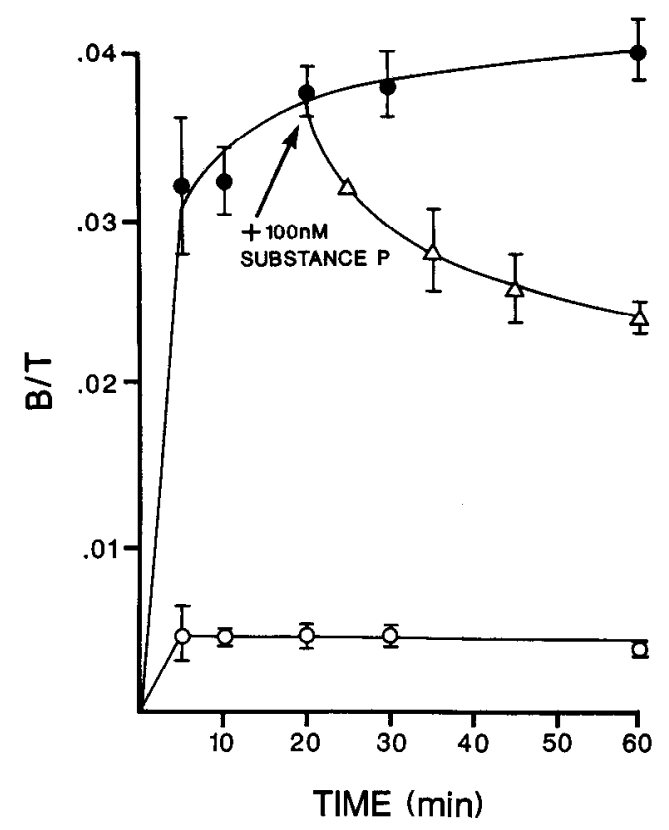

Figure 3. Time course and reversibility of ${ }^{125} \mathrm{I}-$ Bolton-Hunter substance $\mathrm{P}$ binding to dispersed chief cells. A dispersed cell preparation enriched in chief cells by elutriation was incubated with $50 \mathrm{pm}^{125} \mathrm{I}-$ Bolton-Hunter substance $\mathrm{P}$ in the absence (total binding; filled circles) or presence (nonsaturable binding; open circles) of $1 \mu \mathrm{M}$ nonradioactive substance $\mathrm{P}$ at $37^{\circ} \mathrm{C}$. To determine the dissociation of bound ${ }^{125} \mathrm{I}$-BoltonHunter substance $\mathrm{P}, 1 \mu \mathrm{M}$ nonradioactive substance $\mathrm{P}$ was added after incubation for $20 \mathrm{~min}$ with $50 \mathrm{pM}{ }^{125} \mathrm{I}$-Bolton-Hunter substance $\mathrm{P}$ in some tubes (open triangles) and the incubation was continued for an additional $40 \mathrm{~min}$. All values are means \pm SEM of triplicate samples and are representative of 3 experiments.

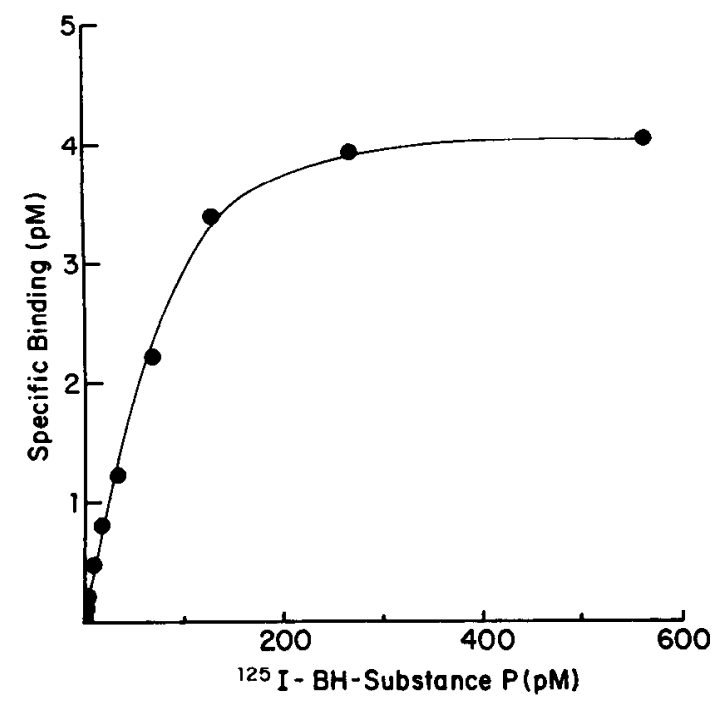

Figure 4. Saturation curve demonstrating the relationship between concentration of ${ }^{125} \mathrm{I}$-Bolton-Hunter substance $\mathrm{P}$ and specific binding to chief cells. A dispersed oxyntic mucosal cell preparation enriched in chief cells by elutriation was incubated with increasing concentrations of ${ }^{125} \mathrm{I}$-Bolton-Hunter substance $P$ for $20 \mathrm{~min}$ at $37^{\circ} \mathrm{C}$. Nonsaturable binding was determined at each label concentration and subtracted from the values shown. All values are the means of triplicate samples and are representative of 4 experiments.

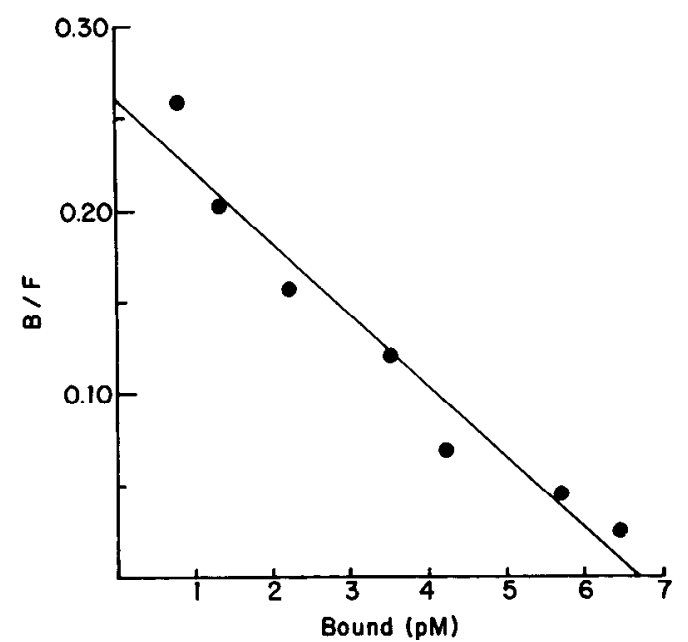

Figure 5. Scatchard plot of ${ }^{125}$ I-Bolton-Hunter substance $P$ specific binding to elutriation-enriched chief cells. Chief cells were incubated at $37^{\circ} \mathrm{C}$ to equilibrium with increasing concentrations of ${ }^{125} \mathrm{I}$-Bolton-Hunter substance $\mathbf{P}$ as described in Figure 4. All values are the means of triplicate determinations and are representative of 4 experiments. For 4 experiments, the average $K_{d}$ was $105 \pm 35 \mathrm{pm}$, and the average $B_{\max }$ was $3050 \pm 2052$ binding sites/cell.

\section{Results}

Autoradiography of specific ${ }^{125}$ I-Bolton-Hunter substance $\mathrm{P}$ binding to sections of the oxyntic region of the canine stomach revealed that the basal portion of the mucosa has a high concentration of putative substance P receptors (Fig. 1). In addition, the walls of blood vessels in the submucosa and the circular layer of external smooth muscle exhibited saturable binding sites for ${ }^{125}$ I-Bolton-Hunter-substance $P$. To identify more precisely the cell type(s) possessing substance $P$ binding sites in the oxyntic mucosa, the saturable binding of ${ }^{125} \mathrm{I}$-Bolton-Hunter substance $P$ to specific cell types was examined using emulsion-coated preparations of dispersed cells affixed to glass slides. We observed specific accumulation of ${ }^{125}$ I-Bolton-Hunter substance $P$ over gastric chief cells, but not parietal cells or mucus-secreting cells (Fig. 2). Additional evidence in support of identification of chief cells as the only source of saturable binding sites for ${ }^{125}$ I-Bolton-Hunter substance $P$ was obtained by determining the amount of saturable binding of the radioiodinated substance $P$ to differential cell fractions prepared using the elutriator rotor. Oxyntic mucosal cells were separated by elutriation into 10 fractions using a protocol previously described (Ayalon et al., 1982). Specific binding of ${ }^{125}$ I-Bolton-Hunter substance $P$ correlated well with chief cell distribution in this cell gradient but not with parietal cell or mucous cell distribution (data not shown).

The binding of ${ }^{125} \mathrm{I}$-Bolton-Hunter substance $\mathrm{P}$ to enriched chief cells was rapid at $37^{\circ} \mathrm{C}$ and reached equilibrium in about 20 min (Fig. 3). Binding was subsequently stable over at least $2 \mathrm{hr}$. When $100 \mathrm{~nm}$ nonradioactive substance $P$ was added to cells previously allowed to bind ${ }^{125} \mathrm{I}$-Bolton-Hunter substance $\mathrm{P}$ to equilibrium, time-dependent dissociation of bound radioligand occurred, reaching about $45 \%$ of the saturably bound level over $40 \mathrm{~min}$ (Fig. 3). Saturable binding was also linearly dependent on the number of cells incubated over at least the range 0.5 to $4 \times 10^{6} \mathrm{cells} / \mathrm{ml}$ (data not shown). Subsequent studies were performed using $2 \times 10^{6}$ cells $/ \mathrm{ml}$ and incubations of 20 $\min$ at $37^{\circ} \mathrm{C}$ unless otherwise noted. 


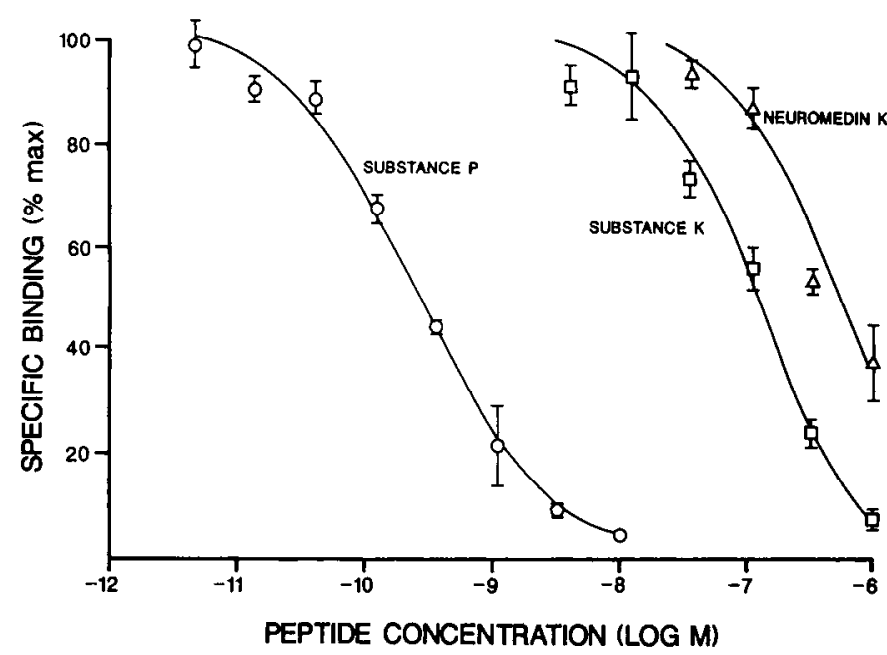

Figure 6. Competitive inhibition of specific binding of ${ }^{125}$ I-BoltonHunter substance $P$ by substance $P$ and other tachykinins. Elutriationenriched chief cells were incubated with $50 \mathrm{pm}{ }^{125}$ I-Bolton-Hunter substance $P$ for $20 \mathrm{~min}$ at $37^{\circ} \mathrm{C}$ with varying concentrations of nonradioactive peptides as shown. Nonsaturable binding was subtracted from total binding, and saturable binding is expressed as the percentage of maximal saturable binding. The amphibian skin tachykinin, physalaemin, was also tested and yiclded a curve virtually identical to that for substance $P$ (not shown). The values shown are means \pm SEM of triplicate determinations and are representative of 4 experiments.

Equilibrium binding of ${ }^{125} \mathrm{I}$-Bolton-Hunter substance $P$ was examined over a range of radioligand concentrations. The binding became saturated at a radioligand concentration of about 300 pM and was half-saturated at about 60 pM (Fig. 4). Scatchard analysis of the saturable binding indicated the presence of a single class of high-affinity, noninteracting binding sites with $K_{d}$ $=105 \pm 35 \mathrm{pM}$ and $B_{\max }=3050 \pm 2052$ binding sites/cell (Fig. 5).

A series of displacement curves for the inhibition of the saturable binding of ${ }^{125} \mathrm{I}$-Bolton-Hunter substance $\mathrm{P}$ to chief cells was constructed to determine the specificity of the binding site for substance $P$ and a series of related and unrelated peptides. At a concentration of $1 \mu \mathrm{M}$, gastrin, CCK-8, somatostatin, bombesin, and vasoactive intestinal peptide did not inhibit saturable ${ }^{125} \mathrm{I}-\mathrm{Bolton}-\mathrm{Hunter}$ substance $\mathrm{P}$ binding. Nonradioactive substance $P$ and physalaemin, an amphibian tachykinin, did inhibit binding from about $10 \mathrm{pm}$ to $10 \mathrm{~nm}$ concentrations and appeared to be nearly equipotent (Fig. 6). The mammalian tachykinins substance $\mathrm{K}$ and neuromedin $\mathrm{K}$ were much weaker, requiring approximately 500 and 1000 times higher peptide concentrations to inhibit $50 \%$ of saturable ${ }^{125}$ I-Bolton-Hunter substance $P$ binding than did substance $\mathbf{P}$ and physalaemin, respectively (Fig. 6).

Because isolated canine chief cells do not secrete pepsinogen in response to secretagogues in vitro (Sanders et al., 1983), we studied pepsinogen relcase from isolated gastric glands prepared from the canine oxyntic mucosa. In preliminary studies, we determined that the glands bind ${ }^{125} \mathrm{I}$-Bolton-Hunter substance $P$ with the same time course, affinity, and specificity as did isolated, enriched chief cell preparations (data not shown). This indicates that the methods used to prepare isolated cells and gastric glands do not differentially affect the substance $P$ binding sites. We then determined the ability of substance $P$ to stimulate pepsinogen secretion from gastric glands. We observed dose-

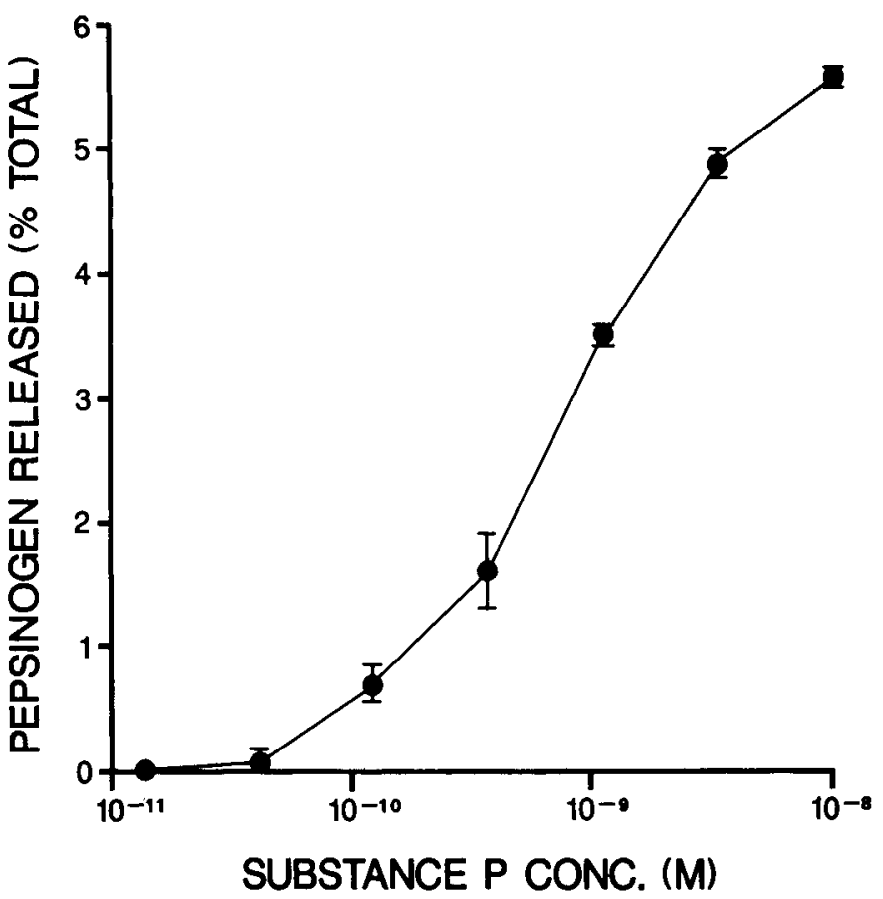

Figure 7. Stimulation of pepsinogen release in vitro by substance $\mathrm{P}$ from gastric glands prepared from oxyntic mucosa. Gastric glands were incubated in triplicate with various concentrations of substance $P$ at $37^{\circ} \mathrm{C}$ for $1 \mathrm{hr}$. Pepsinogen release is expressed as the amount of pepsinogen released into the incubation medium as a percentage of the total amount of pepsinogen present in the glands plus medium at the beginning of the incubation. Basal secretion has been subtracted. There was no further increase or decrease of substance P-stimulated pepsinogen release at doses higher than $10^{-8} \mathrm{M}$. The values shown are means 1 SEM of triplicate determinations and are representative of 3 experiments.

dependent stimulation of pepsinogen release over a substance $P$ concentration range of $0.1-10 \mathrm{nM}$ (Fig. 7). There was no further increase or decrease of substance $\mathrm{P}$-stimulated pepsinogen release at doses higher than $10 \mathrm{~nm}$. One-half maximal stimulation of pepsinogen release occurred at a substance $\mathbf{P}$ dose of about $1 \mathrm{nM}$.

We next examined the ability of substance $P$ to affect intracellular calcium concentrations in enriched chief cell preparations and in gastric glands. We observed a dose-related increase in intracellular calcium concentrations in elutriation-enriched chief cells, density gradient-enriched chief cells, and in gastric glands but not in highly enriched parietal cells (Fig. 8). There was no difference in the effective substance $P$ dose range for affecting intracellular calcium concentration among the 2 cell preparations and the glands. One-half maximal stimulation of intracellular calcium release was obtained at a substance $P$ concentration of approximately $130 \mathrm{pM}$.

\section{Discussion}

The control of pepsinogen secretion from chief cells in the oxyntic mucosa of the mammalian stomach is complex (Hersey et al., 1984; Hersey, 1987). Factors considered to have a direct stimulatory effect on pepsinogen secretion include the neurotransmitters $\mathrm{ACh}$, norepinephrine, and vasoactive intestinal peptide (VIP), and the gastrointestinal peptide hormones cholecystokinin (CCK), and secretin (Hersey, 1987).

The present studies provide the first evidence for the presence 


\section{CHIEF CELLS}

Figure 8. Effect of substance P (SP) on intracellular calcium concentrations in highly enriched chief cells and parietal cells. Elutriation-purified chief and parietal cells were further purified by step density gradient centrifugation to final enrichments of $73 \%$ chief cells and $81 \%$ parietal cells, respectively. The chief cell fraction contained $10 \%$ parietal cells, and the parietal cell fraction contained $9 \%$ chief cells; the remainder of the cell types present in each fraction were mucous cells and undetermined cell types. Cells were loaded by incubation in $1 \mu \mathrm{M}$ FURA-2/AM for $5 \mathrm{~min}$ at $37^{\circ} \mathrm{C}$ and fluorescence in response to substance $P$ was measured at $510 \mathrm{~nm}$ with excitation at $340 / 380 \mathrm{~nm}$. The basal intracellular calcium concentration in the chief cell preparations was $75 \pm 2 \mathrm{~nm}$ and in the parietal cell preparations, $79 \pm 5 \mathrm{~nm}$. Intracellular calcium concentrations were increased to $122 \mathrm{nM}$ in chief cells in response to $10^{-8}$ $M$ substance $P$. Intracellular calcium concentration in parietal cells was unaffected by $10^{-8} \mathrm{M}$ substance $\mathrm{P}$.
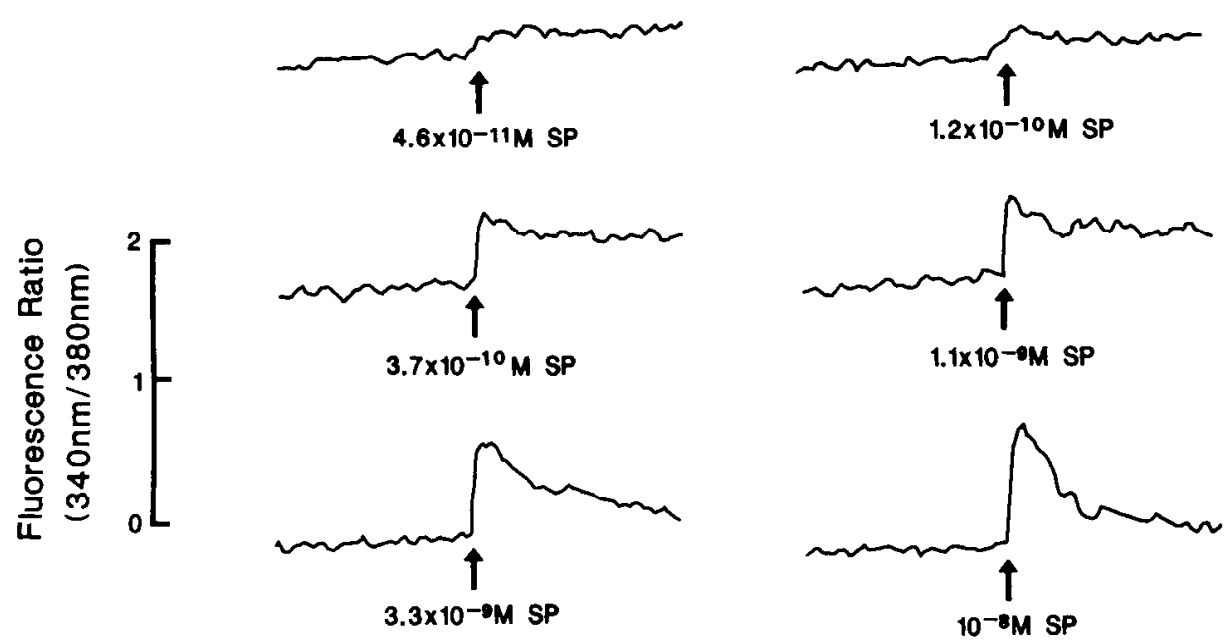

PARIETAL CELLS

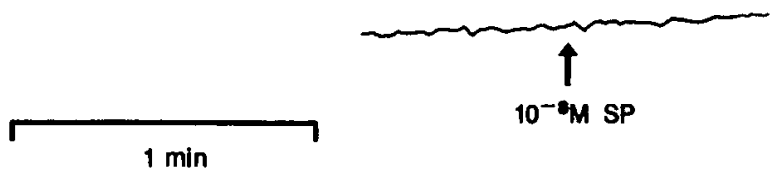

of substance $P$ receptors mediating pepsinogen secretion on canine chief cells. Saturable binding sites for ${ }^{125} \mathrm{I}$-Bolton-Hunter substance $P$ were localized to the chicf cell region of intact oxyntic mucosa and to isolated chief cells by direct localization using autoradiography. The saturable binding of the radioligand correlated with chief cell content in isolated cell preparations and not with parietal cell or mucous cell content.

The binding of ${ }^{125} \mathrm{I}$-Bolton-Hunter substance $\mathrm{P}$ to chief cells was specific, saturable, reversible, time- and cell number-dependent, and of high affinity. The binding appeared to be to a single class of noninteracting sites and was specific for substance $\mathrm{P}$. The $K_{d}$ of $105 \mathrm{pm}$ estimated from equilibrium binding analysis indicated that the ${ }^{125} \mathrm{I}$-Bolton-Hunter substance $\mathrm{P}$ saturable binding site was a high affinity for substance $P$ comparable to that of substance $P$ receptors described in other tissues such as rat brain (Wolf et al., 1985), rat parotid gland (Liang and Cascieri, 1981), and guinea pig (Jensen and Gardner, 1979) and rat (Womack et al., 1985) pancreas. Competitive inhibition studies with substance $P$ and related tachykinins demonstrated that the canine chief cell binding site is highly selective for substance $P$ and amphibian skin tachykinin physalaemin, indicating that this site is of the substance P-preferring tachykinin binding site (Lee et al., 1982; Cascieri et al., 1985; Harada et al., 1987; Mantyh et al., 1989). This is consistent with our earlier observation that the canine oxyntic mucosa exhibits saturable binding of radioiodinated substance $P$ but not radioiodinated substance $K$ or neuromedin K (Mantyh et al., 1988b).

The relationship between substance $P$ binding and stimulation of chief cell function was examined from 2 standpoints. First, the ability of substance $P$ to stimulate pepsinogen release from gastric glands in vitro was examined. Because we had localized the substance $P$ receptor to chief cells and not to the other cell types present in gastric glands prepared from the oxyntic mucosa of the dog stomach, we reasoned that any observed effects of the peptide were direct actions of substance $P$ on chief cells. The concentration of nonradioactive substance $P$ that inhibited onc-half of the specific binding of ${ }^{125} \mathrm{I}$-Bolton-Hunter substance $P$ to chief cells ( 260 pM) was in fairly good agreement with the concentration of substance $P(1 \mathrm{nM})$ that stimulated half-maximal release of pepsinogen from gastric glands. In guinea pig pancreatic acini, substance $P$ has been reported to be more potent for stimulation of amylase release than for inhibition of binding of radioiodinated physalaemin (Jensen and Gardner, 1979). Second, we examined the ability of substance $P$ to elevate intracellular calcium concentrations in highly enriched chief cells and gastric glands. Substance P stimulated increases in cytoplasmic calcium concentrations identically in elutriated chief cell preparations, highly enriched chief cells, and in gastric glands; substance $P$ had no effect on cytoplasmic calcium concentrations in highly purified parietal cells. There was excellent agreement between the concentrations of substance $P$ inhibiting one-half maximal binding ( $260 \mathrm{pM})$ and stimulating one-half maximal intracellular calcium concentrations (130 pM).

It has previously been reported that physalaemin, which has been reported to be a high-affinity ligand specific for the substance $P$ receptor in mammals (Jensen and Gardner, 1979; Wolf et al., 1985), stimulates pepsinogen secretion from dispersed gastric glands prepared from the rabbit stomach (Kasbekar et al., 1983). However, physalaemin stimulated only a $50 \%$ increase over basal levels of pepsinogen release at a dose of 100 nM and was apparently a much weaker agonist than CCK and carbachol in this system. Our present results indicate that substance $\mathrm{P}$ is a much more potent agonist for pepsinogen secretion from canine gastric glands than is physalaemin stimulation of pepsinogen secretion from rabbit gastric glands (Kasbekar et al., 1983). Furthermore, the potency of substance $P$ to stimulate pepsinogen secretion from canine gastric glands is similar to the potency of CCK (Kasbekar et al., 1983; Hersey et al., 1984) and 
much higher than the potency of carbachol (Sanders et al., 1983). Whether the differences between physalaemin action on rabbit gastric glands and substance $P$ action on canine gastric glands is due to use of different species, peptides, or possibly a difference in receptor type remains for future investigation to resolve.

Tachykinin-mediated pepsinogen secretion may have been established early in vertebrate evolution because physalaemin, eledoisin, and substance $P$ have been demonstrated to stimulate pepsinogen secretion in vivo in a bony fish, the cod (Holstein and Cederberg, 1986), and in a frog (Inoue et al., 1987). It is not known if these are direct effects on peptic cells in these species. However, the persistence of tachykinin stimulation of pepsinogen secretion for 350-400 million years of evolution suggests that this is an important component of regulation of peptic cells in vertebrates.

Substance $P$ has been shown to act via specific receptors coupled to inositol phospholipid metabolism in several areas of the brain (Mantyh et al., 1984). Also, increases in cytosolic calcium concentrations have been demonstrated to stimulate pepsinogen secretion from guinea pig chief cells in vitro (Raufman et al., 1986). It remains for future studies to determine whether the substance P-stimulated increases in chief cell cytosolic calcium concentrations are mediated by substance P-stimulated phosphoinositide breakdown. The present study has identified an excellent model system to explore the signal-transduction pathways linked to substance $P$ receptors.

In summary we have outlined a tcchnique for the corrclation of a specific binding site with a functional receptor, provided that methods for obtaining enriched populations of the subject cells are available. A putative target tissue is screened for the presence of a specific and pharmacologically relevant binding site using quantitative receptor autoradiography. The cell type expressing the binding site is then confirmed at the single-cell level using a dispersed cell preparation that allows unequivocal single-cell resolution. The cells expressing the receptor binding sites are then enriched and the pharmacology of the receptor binding site further defined. The second-messenger system(s) employed upon receptor activation can then be studied using these isolated cells. Finally, if the cell type expressing the receptor has a known function, the effect of receptor occupancy on this function can be explored.

\section{References}

Anson, M. L., and A. E. Mirsky (1932) The estimation of pepsin with hemoglobin. J. Gen. Physiol. 16: 59-63.

Ayalon, A., M. J. Sanders, L. P. Thomas, D. A. Amirian, and A. H. Soll (1982) Electrical effects of histamine on monolayers formed in culture from enrichcd caninc gastric chicf cclls. Proc. Natl. Acad. Sci. USA 79: 7009-7013.

Bradford, M. M. (1976) A rapid and sensitive method for the quantitation of microgram quantities of protein utilizing the principle of protein-dye binding. Anal. Biochem. 72: 248-254.

Bury, R. W., and M. L. Mashford (1976) Interactions between local anesthetics and spasmogens on the guinea pig ileum. J. Pharmacol. Exp. Ther. 197: 633-640.

Bury, R. W., and M. L. Mashford (1977) A pharmacological investigation of synthetic substance $P$ on the isolated guinea-pig ileum. Clin. Exp. Pharmacol. Physiol. 4: 453-461.

Cascieri, M. A., G. G. Chicchi, and T. Liang (1985) Demonstration of two distinct tachykinin receptors in rat brain cortex. J. Biol. Chem. 260: 1501-1507.

Harada, Y., T. Takahashi, M. Kuno, K. Nakayama, Y. Masu, and S. Nakanishi (1987) Expression of two different tachykinin receptors in Xenopus oocytes by exogenous mRNAs. J. Neurosci. 7: 32653273.

Herkenham, M., and C. B. Pert (1982) Light microscopic localization of brainopiate receptors: A general autoradiographic method which preserves tissue quality. J. Neurosci. 2: 1129-1149.

Hersey, S. J. (1987) Pepsinogen secretion. In Physiology of the Gastrointestinal Tract, 2nd ed., L. R. Johnson, ed., pp. 947-957, Raven, New York.

Hersey, S. J., S. H. Norris, and A. J. Gibert (1984) Cellular control of pepsinogen secretion. Annu. Rev. Physiol. 46: 393-402.

Holstein, B., and C. Cederberg (1986) Effects of tachykinins on gastric acid and pepsin secretion and on gastric outflow in the Atlantic cod, Gadus morhua. Am. J. Physiol. 250: G309-G315.

Inoue, M., N. Harada, T. Shirakawa, and G. Kajiyama (1987) Effect of substance $P$, its analogs and its fragments on pepsinogen secretion from frog esophageal peptic gland. Gastroenterology 92: 1447.

Jensen, R. T., and J. D. Gardner (1979) Interaction of physalaemin, substance $P$, and eledoisin with specific membrane receptors on pancreatic acinar cells. Proc. Natl. Acad. Sci. USA 76: 5679-5683.

Kachur, J. F., R. J. Miller, M. Field, and J. Rivier (1982) Neurohormonal control of ileal electrolyte transport. II. Neurotensin and substance P. J. Pharmacol. Exp. Ther. 220: 456-463.

Kasbekar, D. K., R. T. Jensen, and J. D. Gardner (1983) Pepsinogen secretion from dispersed glands from rabbit stomach. Am. J. Physiol. 244: G392-G396.

Katayama, Y., and R. A. North (1979) The action of substance P on neurons of the myenteric plexus of the guinea pig small intestine. Proc. R. Soc. London 206: 191-208.

Lee, C.-M., L. L. Iversen, M. R. Hanley, and B. E. B. Sandberg (1982) The possible existence of multiple receptors for substancc P. Naun.Schmied. Arch. Pharmacol. 318: 281-287.

Lembeck, F., and P. Holzer (1979) Substance P as a neurogenic mediator of antidromic vasodilatation and neurogenic plasma extravasation. Naun.-Schmied. Arch. Pharmacol. 310: 175-183.

Liang, T., and M. A. Cascieri (1981) Substance P receptor on parotid cell membranes. J. Neurosci. 1: 1133-1141.

Malfors, G., S. Leander, E. Brodin, R. Hakanson, T. Holmin, and F. Sundler (1981) Peptide-containing neurons intrinsic to the gut wall. An experimental study in the pig. Cell Tissue Res. 214: 225-238.

Mantyh, P. W., R. D. Pinnock, C. P. Downes, M. Goedert, and S. P. Hunt (1984) Correlation between inositol phospholipid hydrolysis and substance $P$ receptors in rat CNS. Nature 309: 795-797.

Mantyh, C. R., T. S. Gates, R. P. Zimmerman, M. L. Welton, E. P. Passaro, Jr., S. R. Vigna, J. E. Maggio, L. Kruger, and P. W. Mantyh (1988a) Receptor binding sites for substance P, but not substance K or neuromedin $\mathrm{K}$, are expressed in high concentrations by arterioles, venules, and lymph nodules in surgical specimens obtained from patients with ulcerative colitis and Crohn disease. Proc. Natl. Acad. Sci. USA 85: 3235-3239.

Mantyh, P. W., C. R. Mantyh, T. Gates, S. R. Vigna, and J. E. Maggio (1988b) Receptor binding sites for substance $P$ and substance $K$ in the canine gastrointestinal tract and their possible role in inflammatory bowl disease. Neuroscience 25: 817-837.

Mantyh, P. W., T. Gates, C. R. Mantyh, and J. E. Maggio (1989) Autoradiographic localization and characterization of tachykinin receptor binding sites in the rat brain and peripheral tissues. J. Neurosci. 9: 258-279.

McPherson, G. A. (1985) Analysis of radioligand binding experiments: A collection of computer programs for the IBM PC. J. Pharmacol. Methods 14: 213-228.

Minagawa, H., S. Shiosaka, H. Inoue, N. Hayashi, A. Kasahara, T. Kamata, M. Tohyama, and Y. Shiotani (1984) Origins and threedimensional distribution of substance P-containing structures in the rat stomach using whole-mount tissue. Gastroenterology 86: 51-59.

Munson, P. J., and D. Rodbard (1980) LIGAND: A versatile computerized approach for the characterization of ligand binding systems. Anal. Biochem. 107: 220-239.

Nieber, K., K. Milenov, J. Bergmann, and P. Oehme (1981) Contractile response of longitudinal and circular muscle of the guinea pig stomach and ileum to substance P. Acta Biol. Med. 40: 209-216.

Raufman, J. P., S. Berger, L. Cosowsky, and E. Straus (1986) Increases in cellular calcium concentration stimulate pepsinogen secretion from dispersed chief cells. Biochem. Biophys. Res. Commun. 137: 281285.

Sanders, M. J., D. A. Amirian, A. Ayalon, and A. H. Soll (1983) Regulation of pepsinogen release from canine chief cells in primary monolayer culture. Am. J. Physiol. 245: G641-G646.

Schultzberg, M., T. Hökfelt, G. Nilsson, L. Terenius, J. F. Rehfeld, M. 
Brown, R. Elde, M. Goldstein, and S. Said (1980) Distribution of peptide- and catecholamine-containing neurons in the gastro-intestinal tract of rat and guinea pig: Immunohistochemical studies with antisera to substance $P$, vasoactive intestinal peptide, enkephalins, gastrin/cholecystokinin, neurotensin and dopamine B-hydroxylase. Neuroscience 5: 689-744.

Sharkcy, K. A., R. G. Williams, and G. J. Dockray (1984) Sensory substance $P$ innervation of the stomach and pancreas: Demonstration of capsaicin-sensory neurons in rat by combined immunohistochemistry and retrograde tracing. Gastroenterology 87: 914-921.

Soll, A. H. (1978) The actions of secretagogues on oxygen uptake by isolated mammalian parietal cells. J. Clin. Invest. 61:370-380.
Soll, A. H., D. A. Amirian, L. P. Thomas, T. J. Reedy, and J. D. Elashoff (1984) Gastrin receptors on isolated canine parietal cells. J. Clin. Invest. 73: 1434-1447.

Wolf, S. S., T. W. Moody, R. Quirion, and T. L. O'Donohue (1985) Biochemical characterization and autoradiographic localization of central substance $P$ receptors using $\left[{ }^{125} I\right]$ physalaemin. Brain. Res. 332: 299-307.

Womack, M. D., M. R. Hanley, and T. M. Jessell (1985) Functional substance $P$ receptors on a rat pancreatic acinar cell line. J. Neurosci. 5: $\mathbf{3 3 7 0 - 3 3 7 8 .}$ 